\title{
Brand Politik Presiden Jokowi Di Kanal Berita Daring
}

\author{
Suci Marini Novianty \\ Program Studi Ilmu Komunikasi, Universitas Pembangunan Jaya \\ Tangerang Selatan, Banten 15413, Indonesia \\ suci.marini@upj.ac.id
}

Received 10 January 2019, Revised 28 August 2019, Accepted 17 September 2019

\begin{abstract}
This study examined empirically the image of the Jokowi brand as an incumbent in the news that aired on three online news pages with the most accessers in Indonesia, Tribunnews.com; Detik.com; and Liputan6.com within the framework of his first period presidency in 2014 - 2018. Researchers took the focus that the brand was built from embedded brand associations, selected issues, the visibility and valence of the news as seen from the news sentiment. Researchers also explored political mediation and a permanent campaign carried out by Jokowi, incumbent in the 2019 Presidential Election. Results found that there were differences between the brand that was built by Jokowi when he became a candidate in 2014 and the first period of being president. However, there are similarities that Jokowi's media coverage is more positive than negative. This finding implies that the political brand image built by Jokowi is indeed influenced by the brand association that is associated with his name, the issues reported by the mass media, to the placement of descriptions about himself and sentiment in the content of the news.
\end{abstract}

Keywords: Online news, Political brand, Jokowi, Incumbent

\begin{abstract}
Abstrak - Penelitian ini secara empiris meneliti citra brand Jokowi sebagai seorang petahana dalam berita-berita yang tayang di tiga laman berita daring dengan pengakses terbanyak di Indonesia, Tribunnews.com; Detik.com; dan Liputan6.com dalam kerangka pemerintahan periode pertama dalam rentang waktu tahun 2014 - 2018. Peneliti mengambil fokus bahwa brand dibangun dari asosiasi brand yang disematkan, isu yang dipilih, hingga visibility dan valensi berita yang terlihat dari sentimen pemberitaan. Peneliti juga menggali mediatisasi politik serta kampanye permanen yang dilakukan oleh Jokowi, petahana pada Pilpres 2019. Hasilnya, peneliti menemukan bahwa terdapat perbedaan antara brand yang dibangun oleh Jokowi saat menjadi kandidat pada 2014 dan presiden periode pertama. Namun terdapat kesamaan bahwa pemberitaan Jokowi lebih banyak bernada positif dibandingkan negatif. Temuan ini mengimplikasikan bahwa citra brand politik yang dibangun oleh Jokowi, memang dipengaruhi oleh asosiasi brand yang dikaitkan dengan namanya, isu yang diberitakan oleh media massa, hingga penempatan deskripsi tentang dirinya serta sentimen dalam konten pemberitaan.
\end{abstract}

Kata Kunci: Berita daring, Brand politik, Jokowi, Petahana

\section{PENDAHULUAN}

Era kepemimpinan Presiden Joko Widodo atau Jokowi resmi dimulai pasca pelantikannya pada 20 Oktober 2014. Jokowi mengalahkan rivalnya, Prabowo, pada putaran kedua pemilihan umum dengan 53,15 persen suara dibandingkan PrabowoHatta yang hanya mendapatkan 46,85 persen suara (tribunnews.com).

Setelah menjadi presiden, ciri khas 'sederhana' Jokowi dan 'kedekatan'-nya dengan warga tetap terjadi. Dalam kunjungannya ke berbagai daerah, seringkali Jokowi melakukan 'blusukan' ke pasar tradisional atau pusat perbelanjaan untuk sekedar melihat usaha lokal yang berkembang di sana.

Adapun menurut Salamah (2015) saat melakukan kampanye pemilihan umum presiden tahun 2014 silam, Jokowi memiliki brand yang berbeda dari pemimpin politik pada umumnya. Brand Jokowi diasosiasikan sebagai pemimpin politik yang turun lapangan, membumi, ramah, merakyat, dan jujur. Sedangkan, pada umumnya brand pemimpin politik diasosiasikan dengan sukses, mapan, cerdas, kaya, dan sehat.

Berbagai kegiatan Jokowi, seringnya diberitakan dalam tone positif oleh media massa, baik konvensional atau pun daring. Dalam artikel laporan penelitian yang dimuat oleh Bernas Jogja, edisi 30 Juli 2013 (Perbawaningsih, 2013), 'media darling' adalah tokoh popular yang sering memperoleh perhatian dan menyenangkan media berita. Jika pada tahun 2009 ikon media darling dari Susilo Bambang Yudhoyono (SBY), maka di tahun 2013, Jokowi yang kala itu menjabat sebagai Gubernur DKI Jakarta lah yang dituju. Fenomena ini kemudian dapat dikaitkan dengan teori agenda setting, sebagai salah satu teori yang mengasumsikan bahwa media massa memiliki kekuatan yang besar untuk mempengaruhi publik. 
Ketika Jokowi diberitakan dengan frekuensi tinggi dan tone yang positif, publik pun akan memandangnya dengan positif pula. Hal ini juga ditengarai sebagai gejala dari mediatisasi politik di Indonesia sehingga Jokowi terbedakan dari para pesaingnya. Mediatisasi politik membuktikan bahwa media tidak lagi hanya menjadi subordinat dalam politik yang bersifat statis.

Isu mengenai branding politik Presiden Jokowi di media massa daring dalam momentum 3 tahun pemerintahannya menarik untuk ditelaah lebih lanjut karena pada penelitian yang dilakukan pada saat pemilihan presiden tahun 2014, ditemukan bahwa ciri - ciri brand yang dibangun oleh Presiden Jokowi adalah membangun partisipasi (Salamah, 2015). Pemikiran masayarakat terhadap brand Jokowi yang tertanam lekat dikarenakan proses branding yang dilakukan oleh Jokowi tidak lagi hanya berada dalam tataran brand identity atau brand position, melainkan sudah mendalam hingga masuk ke pola brand image yang berbicara mengenai persepsi masyarakat terhadap brand tersebut.

Jokowi dengan kemungkinannya menjabat untuk kedua kali, kemudian melakukan kampanye permanen. Kampanye permanen sejatinya adalah tentang mempertahankan citra diri isu-isu yang ditayangkan di media massa. Isu-isu ini hadir melalui program dan kegiatan selama menjabat atau saat secara langsung presiden turun ke lapangan mau pun hal-hal yang terliput dan ditayangkan di media massa.

\section{Latar Belakang}

Berdasarkan dokumen visi dan misi Jokowi - JK yang dikumpulkan kepada Komisi Pemilihan Umum (KPU) per Mei 2014, visi yang diusung oleh Jokowi pada pemerintahannya adalah "Terwujudnya Indonesia yang Berdaulat, Mandiri, dan Berkepribadian Berlandaskan Gotong Royong."

Pemerintahan Jokowi - JK juga identik dengan Nawacita. Berupa 9 poin agenda kerja yang menjadi fokus dalam implementasi program - program di isu kemaritiman, politik, hukum, Hak Asasi Manusia (HAM), infrastruktur, hingga perbatasan.

Pada 20 Oktober 2017, pemerintahan Presiden Jokowi genap 3 tahun berjalan. Setiap tahun, berbagai lembaga survei independen mengeluarkan hasil riset yang mereka lakukan dalam mengukur kepuasan masyarakat Indonesia terhadap kinerja pemerintah. Tabel 1 adalah hasil survei untuk tahun 2017.

Tabel 1. Hasil Survei tahun 2017 (dalam \%)

\begin{tabular}{lccccc}
\hline \multicolumn{2}{c}{ CSIS } & \multicolumn{2}{c}{ SMRC } & \multicolumn{2}{c}{ PC } \\
\hline $\mathrm{P}$ & TP & P & TP & P & TP \\
68,3 & 31,7 & 61 & 39 & 62 & 35,1
\end{tabular}

*CSIS (Center for Strategic and International Studies)

*SMRC (Saiful Mujani Research and Consulting)

*PC (Populi Center), P (Puas) dan TP (Tidak Puas)

Litbang Kompas menemukan, bahwa kepuasaan tertinggi terhadap pemerintahan Jokowi - JK berada di luar Pulau Jawa. Dapat disimpulkan bahwa secara umum pembangunan yang dilakukan oleh pemerintahan Jokowi - JK sudah mendapatkan apresiasi dari masyarakat. Hal ini ditunjukan dengan angka kepuasan yang terus meningkat. Namun, dibandingkan masyarakat yang tinggal di Pulau Jawa, pembangunannya justru lebih dirasakan oleh masyarakat di luar Pulau Jawa.

Presiden Jokowi, sebagai presiden ke-7 Republik Indonesia sendiri sudah memiliki citra sebagai pemimpin yang bekerja keras untuk rakyatnya. Sebagai Walikota, Jokowi terkenal dengan metode 'blusukan'-nya. Menurut Indrananto (2012) dalam penelitiannya yang berjudul "Pemimpin Lokal dan Agen: Dramaturgi dalam Komunikasi Politik Walikota Solo, Joko Widodo", pola hubungan yang interaktif dengan masyarakat Kota Solo, membuat Jokowi mendapatkan kepercayaan mereka.

Pada tahun 2012, saat menjabat sebagai Gubernur DKI Jakarta, 'blusukan' masih menjadi hal yang sering dilakukan oleh Jokowi. Citra Jokowi yang lekat dengan kemeja putih dan celana bahan hitamnya, berbeda jauh dengan tampilan gubernur - gubernur sebelumnya. Dengan demikian, masyarakat merasa lebih dekat dan tidak sungkan untuk menceritakan masalah-masalah yang mereka hadapi.

Sebagai seorang politisi, Jokowi memang harus memiliki identitas untuk ditampilkan di hadapan publik. Sebab brand yang ia miliki harus mampu berinteraksi dengan masyarakat. Khususnya, guna mendapatkan dukungan dari media. Media memiliki andil penting dalam hal penyampaian informasi. Media dibutuhkan untuk menyampaikan informasi, melakukan edukasi hingga menyediakan platform untuk menampung dan medium terbentuknya opini publik sekaligus memberi advokasi sudut pandang politik dengan kontennya.

Jokowi terbedakan dari para pesaingnya karena proses mediatisasi politik yang terjadi saat ini di Indonesia. Mediatisasi politik membuktikan bahwa media tidak lagi hanya menjadi subordinat dalam politik yang bersifat statis. Media massa menjadi katalisator dalam perubahan keseharian politik, dengan logika media yang dengan cepat menyebar ke berbagai lembaga sosial, seperti partai politik dan publiknya. Maka menjadi penting untuk membentuk citra, baik partai mau pun aktor politik di media massa (Urfan, 2011).

Pada akhirnya, Jokowi merupakan produk dari proses pemasaran politik yang dapat diakui berhasil dengan kemenangannya pada Pemilu Presiden, 2015 silam. Setelah jatuhnya Orde Baru, politik tidak lagi tabu untuk terus diekspos. Marketing politik, adalah penggabungan teknik marketing sosial dan konsepkonsep dalam politik (Lees-Marshment, 2009). Lebih lanjut, partai politik sebagai organisasi pengusung aktor politik juga melakukan langkah-langkah dalam proses pemasaran. Seperti profiling pemilih, segmentasi, micro-targeting, hingga strategi emarketing untuk menginformasikan janji kampanye mereka. Pemilih adalah pasar bagi mereka, sehingga 
program yang ditawarkan didasarkan kepada keinginannya.

Isu mengenai Branding politik Presiden Jokowi di media massa daring dalam momentum 3 tahun pemerintahannya menarik untuk ditelaah lebih lanjut karena pada penelitian yang dilakukan pada saat pemilihan presiden tahun 2014, ditemukan bahwa ciri-ciri brand yang dibangun oleh Presiden Jokowi adalah membangun partisipasi (Salamah, 2015). Pemikiran masayarakat terhadap Brand Jokowi yang tertanam lekat dikarenakan proses Branding yang dilakukan oleh Jokowi tidak lagi hanya berada dalam tataran Brand identity atau Brand position, melainkan sudah mendalam hingga masuk ke pola Brand image yang berbicara mengenai persepsi masyarakat terhadap brand tersebut.

Maraknya pemberitaan positif di media massa, juga menguatkan Branding politik Jokowi. Brand politik pemimpin politik menurut Salamah (2015) merupakan pesan yang memuat identitas sosial dan digunakan agar mudah dicerap oleh pengikut. Brand sebenarnya adalah nama, istilah, tanda, simbol, rancangan, atau kombinasi dari kesemuanya, dibuat agar barang atau jasa dapat dibedakan dari pesain (Kotler, 2009). Menurut Kornberger (2010) Brand memiliki kemampuan untuk memberikan dan mempertegas identitas pada produk.

Mempertegas hal tersebut, persepsi masyarakat modern mengenai politik ditentukan oleh potongan potongan citra yang diberikan oleh media massa. Citra yang kemudian dimiliki oleh pemilih tentang seorang pemimpin, sejatinya adalah hasil predisposisi dari media. Media adalah wahana sosialisasi bahasabahasa simbolik yang membentuk citra pemimpin ideal.

Melihat perbedaan brand yang dibangun oleh Jokowi saat menjadi seorang petahana penting untuk dibandingkan karena sebagai seorang presiden yang baru pertama kali memenangkan kursi kepemimpinan, artinya Jokowi masih memiliki kesempatan untuk menjabat pada periode selanjutnya. Berdasarkan Pasal 7 UUD 1945 hasil amandemen di tahun 1999, "Presiden dan Wakil Presiden memegang jabatan selama lima tahun, dan sesudahnya dapat dipilih kembali dalam jabatan yang sama, hanya untuk satu kali masa jabatan." Untuk mendapatkannya, maka Jokowi membutuhkan upaya untuk memelihara kekuatan brand yang ia miliki saat kampanye pertama.

Disinilah konsep 'permanent campaign' muncul. Kampanye permanen sejatinya adalah tentang mempertahankan citra diri isu-isu yang ditayangkan di media massa. Isu-isu ini hadir melalui program dan kegiatan selama menjabat atau saat secara langsung presiden turun ke lapangan mau pun hal-hal yang terliput dan ditayangkan di media massa. Nantinya, pertanyaan mengenai 'Apakah Presiden Jokowi masih dipersepsikan sama oleh media massa?'

Penjabaran latar belakang isu ini kemudian mengantarkan ke rumusan permasalahan tentang kampanye permanen yang dilakukan oleh Jokowi sebagai presiden dan calon petahana pada pemilu selanjutnya. Bentuk kampanye permanen yang dilakukan, salah satunya dengan membiarkan media massa meliput kegiataannya saat turun ke masyarakat dan berjalannya pembangunan. Sedangkan, dewasa ini, media massa sudah berevolusi hingga dapat hadir dengan mudah dalam genggaman, yaitu dengan kemunculan media massa daring.

Menurut penelitian yang dilakukan oleh Indonesian Digital Association (IDA) pada 2016, ponsel pintar paling banyak digunakan untuk mengakses berita online. Penelitian lain yang dilakukan oleh UC Browser di tahun yang sama mengklaim bahwa 95,4 persen pengguna internet di Indonesia membaca konten berita melalui ponsel pintar. Hanya 45,9 persen yang mengaksesnya dari televisi, 20,9 persen dari majalah atau koran, 15,3 persen dari computer, serta 6,7 persen mengaksesnya melalui radio. Meskipun jumlah ini belum dapat menyaingi televisi sebagai media yang paling banyak diakses di Indonesia pada tahun 2017, 92 persen (Hootsuite.com), namun adanya pergeseran pola konsumsi, khususnya berita sudah mulai terlihat.

Konsep dan fenomena yang berkembang di masyarakat berkenaan dengan Branding politik di media massa daring ini akan menjadi dasar penelitian yang berfokus pada Presiden Jokowi selama 3 tahun pemerintahannya.

\section{Formulasi Masalah}

Penelitian ini berupaya untuk menelaah perkembangan citra politik Jokowi pada tiga tahun pertama pada periode pertama pemerintahannya. Membandingkan apakah terjadi perubahan brand yang dibangun pada saat kampanye pemilihan presiden dan berjalannya pemerintahan. Penelitian dengan topik brand seorang petahana di Indonesia, secara khusus belum pernah dilakukan.

Peneliti juga memilih menggunakan situs berita daring pada penelitian mengenai citra brand politik seorang presiden sebagai objek penelitian karena belum pernah dilakukan sebelumnya. Padahal, dewasa ini berita daring semakin mudah diakses seiring dengan perkembangan ponsel pintar, khususnya di Indonesia. Untuk mendapatkan informasi yang cepat dan teraktual, situs berita daring menjadi acuan.

Tiga tahun pemerintahan dipilih menjadi fokus penelitian, karena tahun pertama pemerintahan adalah waktu pemimpin masih melanjutkan program kerja dari pendahulunya. Pada tahun kedua, pemimpin baru tersebut diasumsikan, baru memulai program kerjanya sendiri, sehingga hasilnya baru dapat terlihat di tahun ketiga pemerintahannya. Dua tahun terakhir pemerintahannya, pemimpin akan kembali disibukkan dengan pembagian perhatian kepada pemilihan umum lagi.

Di Amerika Serikat, penelitian mengenai keuntungan menjadi seorang petahana pernah dilakukan oleh Mayhew (1974), dengan kesimpulan 
bahwa menjadi petahana memberikan keuntungan saat mencoba untuk menjabat di periode kedua.

Berdasarkan konsep dan fenomena yang sudah dijabarkan pada bagian latar belakang di atas, maka penelitian pertanyaan penelitian yang akan dilakukan adalah sebagai berikut:

1. Seperti apa Brand Jokowi ditampilkan dalam media massa daring;

2. Apa perbedaan antara Brand Jokowi saat kampanye pemilihan presiden dan setelah 3 tahun pemerintahannya;

3. Seperti apa asosiasi brand yang disematkan kepada Jokowi sebagai presiden di media massa?; dan

4. Apa saja isu yang dianggap memperkuat dan atau memperlemah Brand Jokowi oleh situs media daring selama 3 tahun pemerintahannya?

\section{Tujuan}

1. Menganalisis Brand Jokowi yang ditampilkan dalam media massa daring;

2. Mengetahui perbedaan antara Brand Jokowi saat kampanye pemilihan presiden dan setelah 3 tahun pemerintahannya;

3. Mengetahui asosiasi brand yang ditujukan kepada Jokowi sebagai presiden di media massa daring;

4. Mengetahui isu yang dianggap memperkuat dan atau memperlemah Brand Jokowi oleh situs media daring selama 3 tahun pemerintahannya.

\section{Sistematika Penulisan}

Sistematika penulisan dalam penelitian ini dimulai dari penjelasan pendahuluan isu. Pendahuluan isu meliputi latar belakang, formulasi masalah, tujuan, dan sistematika penulisan. Selanjutnya, isu dielaborasi dalam kajian pustaka. Penyajian temuan penelitian, dipaparkan dalam bagian hasil penelitian dan analisis. Terakhir, seluruh penelitian akan dirangkum dalam kesimpulan.

Penelitian ini diharapkan dapat menambah literatur mengenai branding pemimpin politik. Ranah ilmu komunikasi di Indonesia belum banyak topik bahasan yang menggabungkan konsep brand dan dunia politik. Penelitian ini juga diharapkan dapat memberi perspektif baru dalam melihat branding politik pemimpin yang sedang menjabat (petahana) melalui kajian mengenai mediatisasi politik dan manfaatnya bagi kampanye permanen.

\section{KAJIAN PUSTAKA}

Beberapa penelitian yang relevan pada penelitian ini dan masih memiliki kemungkinan untuk dikembangkan diuraikan seperti berikut:

1. Brand Pemimpin Politik (Salamah, 2015) membahas mengenai brand Jokowi pada massa kampanye pemilihan presiden. Hasilnya, ditemukan asosiasi brand para pemimpin politik pada pemilihan presiden tahun 2014 silam;

2. Peran Personal Branding Elit Politik Dalam Pembentukan Identitas Partai Politik (Studi
Deskriptif Kualitatif Personal Branding Prabowo dalam Iklan TVC Partai Gerindra) (Sunaikah, 2014) - membahas mengenai branding elit politik dalam pembentukan branding partai dengan studi kasus pada Prabowo Subianto. Studi ini berbicara tentang partai politik dan kebutuhannya terhadap media massa guna pembentukan personal branding dari elite politiknya;

3. Membaca Gejala 'Mediatisasi' Politik di Indonesia (Urfan, 2011) - berbicara mengenai mediatisasi yang dianggap sebagai sebuah proses dari modernitas, yaitu ketika media menjadi lembaga yang independen dengan logikanya sendiri. Kemudian, lembaga sosial lainnya, terutama partai politik, harus mengikuti logika tersebut;

4. Pengaruh Janji Merek, Reputasi Merek dan Kampanye Permanen terhadap Keyakinan Keputusan serta Intensi Mendukung Partai Politik (Sihite, 2017) - ini fokus pada usaha mengintegrasikan pertukaran dalam pemilihan umum dan pertukaran di dalam pemerintahan, yang bersama-sama merupakan bagian kampanye permanen. Pertukaran di dalam pemilihan umum terjadi ketika partai politik menyampaikan janji partai politik kepada pemilih, pertukaran di dalam pemerintahan terjadi ketika partai politik merealisasikan janjinya. Model ini mengajukan proposisi bahwa realisasi janji partai politik mempengaruhi reputasi partai politik serta mempengaruhi kampanye permanen, dan akhirnya mempengaruhi keyakinan keputusan pemilih untuk mendukung partai politik.

Penelitian yang dilakukan oleh Salamah (2015) masih terdapat celah untuk dikembangkan karena Salamah belum memperluas penelitiannya menjadi asosiasi brand seorang petahana saat ini. Sedangkan penelitian yang dilakukan oleh Sunaikah (2014) dapat dikembangkan dengan mengisi pembentukan personal Branding seorang elite politik dan petahana melalui isu-isu di media massa.

Mengenai kajian mediatisasi politik (Urfan, 2011) masih mungkin untuk peneliti isi dengan tambahan komprehensif bagaimana hal ini memaksa petahana juga untuk mengisi isu positif tentang diri dan kinerja di media massa. Terakhir, pada disertasi Sihite (2017) dimana penelitian ini masih dapat dikembangkan karena Sihite belum membahas dari segi individu yang melakukan janji saat kampanye, hingga praktek kampanye permanen sebagai seorang petahana.

Penelitian ini berangkat dari isu pemasaran politik yang prakteknya terjadi di Indonesia saat ini. Perubahan tradisi politik di Indonesia pasca runtuhnya rezim Orde Baru, memberikan kesempatan tumbuhnya ranah pemasaran politik. Demokratisasi yang menjadi nafas utama reformasi serta era setelahnya, adalah hasil dari liberalisasi politik. Konsep liberalisasi politik adalah dampak dari modernisasi yang berlaku secara global, (Salamah, 2015). 
Lingkungan politik yang demokratis adalah tempat dimana pemerintahan yang berkuasa memimpin dengan mengedepankan persetujuan masyarakat, dibandingkan dengan pemaksaan. Disini, pendapat warga negara menjadi penting dalam membuat keputusan.

Menurut Salamah (2015), liberisasi dan konsumerisme adalah hal yang tidak terpisah. Konsumerisme menghasilkan kebebasan untuk publik sebagai konsumen untuk memilih dalam proses konsumsinya, bahkan termasuk juga di bidang politik. Hal ini kemudian menghasilkan fenomena 'konsumen politik' yang memilih partai politik berdasarkan penawaran layanan kesehatan, pendidikan, transportasi publik, serta program penyelesaian isuisu lainnya.

Partai politik tidak lagi dianggap sebagai kelompok kepentingan dan aktivis yang menjadi aktor utama (Bawn dkk, 2012) atau ekspresi dari identitas kolektif dan aspirasi pendukungnya (Esser \& Pftesch, 2004). Saat ini, partai politik telah memiliki pergeseran fungsi, kali ini sebagai penyedia layanan bagi publik seperti entitas bisnis lainnya (LeesMarshment, 2004; Brants dan Voltmer, 2011 dalam Salamah 2015:2).

Merujuk pada pergeseran fungsi partai politik, maka kebutuhan untuk memasarkan organisasi menjadi penting untuk dilakukan. Tujuannya untuk membuat publik memilih mereka dalam pemilihan umum. Tren pemilih yang menjagokan partai politik dengan kebijakan grass-roots, karena mereka senantiasa mengukuhkan posisi mereka sebagai kendaraan pemilih untuk membuat kebijakan prorakyat dengan keberanian membuat keputusan, dibuktikan dengan performa yang optimal, dan profil yang lebih jelas (Brockhoff dan Kurbjuweit, 1994). Partai politik yang berkuasa juga semakin memahami kekuatan personal seorang aktor politik sebelum mereka berikan sokongan. Sehingga, faktor individu turut menjadi penentu dalam kans elektabilitas sebuah partai politik. Hal ini merupakan hasil dari paham liberalisme (Salamah, 2015).

Pemasaran politik adalah konsep permanen yang harus dilakukan secara terus menerus oleh sebuah partai politik atau kandidat dalam membangun kepercayaan dan citra publik (Butler dan Collins dalam Firmanzah, 2007). Isu pemasaran politik, adalah pemasaran jasa (Harrop, 1990 dalam O’Shaugnessy, 2001) dan merupakan jenis jasa yang bersifat credence, maksudnya kepuasaannya tidak dapat dinikmati barang tersebut dibeli. Sebab, politik menawarkan produk yang abstrak dan tidak kasat mata (intangible), namun hal yang bermuatan nilai (value-laden) dan janji terkait masa depan, pandangan hidup yang menginspirasi, atau apa pun yang kepuasannya tidak bersifat langsung namun bersifat jangka panjang, samar, dan tidak pasti (O’Shaugnessy, 2001).

Menurut Firmanzah (2007) dalam ranah strategi komunikasi politik, pemasaran mengajarkan bagaimana partai politik bisa mendiferensiasikan produk dan citra politiknya di hadapan publik. Harapannya, masyarakat luas akan dapat mengenali identitas partai dan kandidatnya. Citra pun menjadi penting dalam kontestasi kandidat karena citra berimplikasi pada pembahasan mengenai produk politik seperti kompetensi atau kepercayaan yang dimiliki oleh pemimpin. Selain itu, faktor lainnya yang terkandung dalam produk politik adalah kebijakan dan ideologi berdasarkan model konsumen Himmelweit (O’Shaugnessy, 2001).

Pemusatan kampanye menggunakan pemasaran politik, komunikasi dua arah antara partai dan pemilih semakin dianggap penting. Berbagai upaya dilakukan untuk memenuhi kebutuhan tersebut. Melalui tindakan yang diambil terkait dengan kebutuhan pemilih dan bertujuan demi memenangkan pemilihan umum (Salamah, 2015). Apalagi, para pemilih, dewasa ini, lebih kritis, terdidik, melek informasi, dan mandiri dari pengaruh pengaruh partai politik. Penggunaan polling untuk mendapatkan gambaran opini publik, focus group discussion (FGD) untuk mendapatkan masukan tentang kecenderungan pemilih, dan media untuk menyampaikan pesan melalui iklan adalah bentuk nyata pemasaran politik (Salamah, 2015).

Pemasaran politik adalah pendahuluan dari pendekatan brand politik. Keduanya adalah konsep yang dipinjam dari ilmu pemasaran. Pendekatan brand pun merupakan pengembangan dari pendekatan pemasaran (Salamah, 2015).

Brand adalah elemen pembeda yang menambahkan nilai dari suatu produk. Dengan pesan atau simbol yang digunakan untuk membedakan dan mengidentifikasi suatu produk atau jasa serta bertujuan untuk membangun diferensiasi (The Marketing Association, 1960 dalam Heding, Knudtzen, dan Bjerre, 2009; Keller, 2003). Brand mampu untuk mempengaruhi gaya hidup yang dibentuk dari selera, sikap, perilaku, preferensi, hingga kepercayaan, karena brand adalah identitas siap pakai (ready-made) (Kornberger, 2010).

Berikut adalah skema ringkas yang menggambarkan konsep brand secara mendasar:

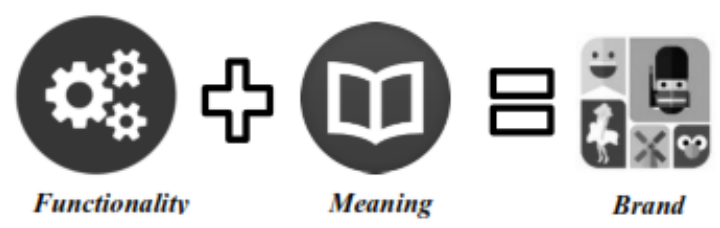

Gambar 1. Konsep Brand (Salamah, 2015)

Kekuatan brand terletak dalam interpretasi orang lain (Kornberger, 2010) dan tidak bermakna jika berdiri sendiri (Kornberger, 2010). Brand, menurut Salamah (2015) adalah pesan yang dikirimkan kepada penerima melalui media. Interaksi brand dengan publik bersifat semu karena interaksi terjalin melalui media massa. Ogden dan Richard (1923 dalam Nimmo, 1978) merumuskan gambar yang 
menunjukan hubungan antara simbol dengan interpretasi makna sebagai berikut:

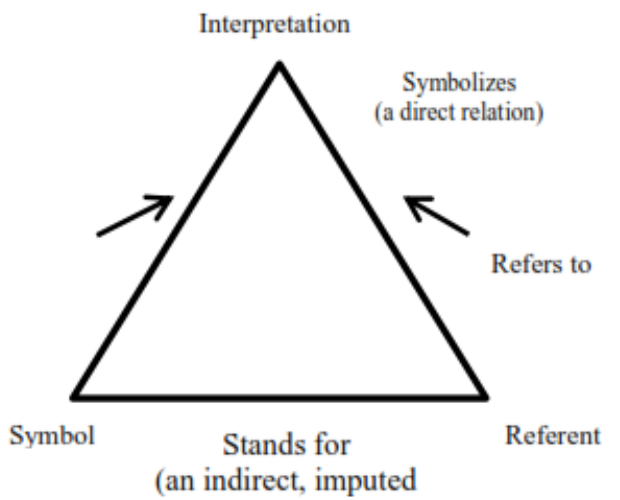

Gambar 2. Hubungan antara simbol dan interpretasi makna

Pada gambar di atas, brand diasosiasikan sebagai simbol. Konberger dalam Salamah (2015) menjelaskan bahwa dalam lingkungan politik yang didorong oleh citra (image-driven) dan bersaturasi di seputar media (media-saturated), simbol menjadi lebih penting dari obyek yang diwakilinya (signified). Lebih lanjut, menurut Kornberger, Jean Baudillard menyebutnya sebagai sebuah hiperrealitas karena simbol (sign) atau citra (image) menjadi lebih riil ketimbang realitas sebenarnya dari sebuah situasi (Kornberger, 2010).

Brand adalah pemenuhan kebutuhan emosi dan ekspresi dari identitas konsumen. Brand memiliki fungsi sebagai instrument identifikasi, memberikan jaminan, optimisasi, label yang sesuai citra diri, kontinuitas, memenuhi kebutuhan hedonistik dan etis (Kapferer, 2008). Hal ini turut pula diamini oleh Batey (2008) bahwa konsumen saat ini tidak lagi melihat konsumsi sebagai pemenuhan kebutuhan fisik saja. Melainkan, juga upaya pemenuhan kebutuhan pembentukan dan pengekspresian identitas diri. Brand adalah bentuk simbolik self-completion dari usaha afirmasi konsumen.

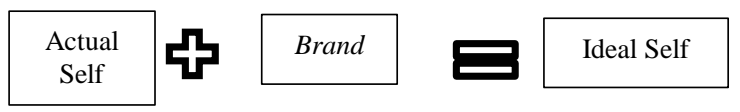

Gambar 3. Ilustrasi ideal self

Kunci dari berhasil suatu usaha membangun brand didasarkan pada konssistensi. Apabila brand konsisten dengan identitas dirinya, maka makna tersebut akan dipindahkan kepada identitas dirinya (Levy, 1959 dalam Taylor, 2010). Makna disini diasosiasikan dengan brand dan individu yang cenderung untuk memilih produk yang mendukung dan mengembangkan citra dirinya untuk mengekspresikan identitas mereka (dalam Salamah, 2015).

Salamah (2015) menyimpulkan bahwa kecenderungan konsumen ini juga sama, terjadi di dalam lingkungan konsumen politik. Maka, selanjutnya, untuk membahas kerangka konsep lebih mendetail, peneliti akan membahas mengenai brand politik.

Masuk ke dalam ranah politik, brand politik merupakan hasil dari pemasaran politik (Salamah, 2015). Berbeda dengan penerapan prinsip branding di berbagai situasi, seperti barang fisik, jasa, took retail, orang, organisasi, tempat, dan ide (Keller, 2008), politik dianggap sebagai ranah yang berbeda dari pasar komersial (dalam Salamah, 2015). Sehingga dalam proses penyesuaian untuk implementasi manajemen brand untuk produk - produk politik (pemimpin, partai, program, dan kebijakan politik) (Salamah, 2015).

Contoh kasus di Indonesia, dalam pemilihan presiden langsung pertama pada 2004 silam, Susilo Bambang Yudhoyono yang datang dari partai baru, Partai Demokrat, bersama dengan pasangannya, Jusuf Kalla, dapat mengalahkan petahana, Presiden Megawati Soekarnoputri dengan Hasyim Muzadi. Salamah (2015) menyimpulkan bahwa apa yang terjadi dengan Partai Demokrat dan Susilo Bambang Yudhoyono (SBY-JK) menunjukan bahwa sosok capres dan cawapresnya menentukan preferensi pemilih, meski mereka datang dari partai - partai dengan reputasi yang belum optimal dengan perolehan suara relatif kecil.

Menggunakan contoh - contoh kasus di atas, ditemukan bahwa sudah tidak relevan lagi untuk memandang kandidat sebagai produk dan partai sebagai brand karena fokus pemilih kini tidak lagi bertumpu pada partai melainkan kandidatnya (Guzman dan Sierra, 2009).

Pembentukan identitas hingga menjadi pesan yang dikomunikasikan kemudian dipersepsikan oleh konsumen sendiri terdari dari 3 lapisan. Aaker (1996:71) menyebutkannya dalam rangkaian:

1. Brand image, how the Brand is now perceived;

2. Brand identity, how the strategies want the Brand to be perceived; dan

3. Brand position, the part of the Brand identity and value proposition to be actively communicated to a target audience.

Namun, Salamah (2015) menyatakan bahwa dewasa ini, ketiga lapisan tersebut dipahami dengan urutan sebagai berikut:

1. Brand identity (Seperangkat asosiasi unik yang dimiliki oleh brand yang harus dibentuk dan dipelihara merepresentasikan apa yang diwakili oleh brand, membantu membangun hubungan antara brand dengan pelanggan karena merupakan janji organisasi kepada pelanggannya. Memiliki identitas inti (core identity) dan identitas perluasan (extended identity) (Aaker, 1996);

2. Brand position (Bagian dari identitas Brand (Brand identity) dan proporsi nilai yang secara aktif dikomunikasikan kepada audiens yang menjadi target. Brand position merupakan sumber program komunikasi untuk suatu brand dengan selalu menunjukan kelebihan brand tersebut 
dibandingkan dengan pesaingnya) (Aaker, 1996); dan

3. Brand image (Konsep mengenai persepsi pelanggan dan pihak lain terhadap brand (saat pengukuran)) (Aaker, 1995).

Proses branding yang disematkan pada para pemimpin politik memiliki resiko:

a. Menjadikan orang sebagai komoditas;

b. Menggeser kampanye politik yang awalnya berpusat pada platform (platform-centered) menjadi berpusat pada sosok kandidat (candidatecentered) yang artinya mengganti substansi dengan pencitraan; dan

c. Menjadikan pemimpin sebagai simulasi dimana individu dinihilkan menjadi retorika dan pencitraan serta menjadi apa yang disebut oleh Baudrillard sebagai simulacrum (gambar palsu yang terlihat dengan nyata) dan consumer society (kapitalisme) (Zavattaro, 2010).

Efek lain dari hadirnya brand politik adalah penyempitan agenda politik, peningkatan konfrontasi, dorongan menuju konformitas terkait perilaku dan pesan dan bahkan menyebabkan ketidakterlibatan (disengagement) di tingkat lokal (dalam Salamah, 2015). Namun, alasan pemilihan suatu produk (termasuk calon pemimpin politik) sebagian karena brand yang dimiliki produk tersebut turut merefleksikan pula identitas diri individu (Ulrich dan Smallwood, 2007). Politik dan brand pun memiliki kesamaan, keduanya berada dalam ranah identitas (Salamah, 2015).

Brand merupakan seperangkat makna yang terdiri dari beberapa konsep kunci (Aaker, 1996; Aaker, 1997 dalam Salamah, 2015):

a. Brand awareness (Kekuatan dari kehadiran Brand dalam benak pelanggan/pengguna yang merupakan tingkat pengenalan (recognition) dan kemampuan mengingat kembali (recall);

b. Brand association (Asosiasi yang terbentuk dalam benak pelanggan mengenai suatu brand baik berupa atribut, endorser, atau simbol tertentu);

c. Bramd equity (Seperangkat asset (dan liabilitas) yang terkait dengan nama dan simbol brand yang menambah (atau mengurangi) nilai yang dimiliki oleh produk dan jasa dari perusahaan dan/atau pelanggan atau pengguna perusahaan tersebut);

d. Brand personality (Seperangkat karakteristik manusia yang diasosiasikan dengan sebuah brand).

Penelitian mengenai brand Jokowi kali ini akan berfokus pada tataran brand association atau asosiasi brand. Sehingga kata benda (noun) dan kata sifat (adjective) yang diasosiasikan dengan Jokowi sebagai presiden akan menjadi landasan penelitian.

Brand association atau asosiasi brand menurut Aaker (1996) adalah segala sesuatu yang dimiliki oleh brand dan dikaitkan dengan memori mengenai brand tersebut. Keller (1998) mendefinisikannya sebagai informasi yang berhubungan dengan bagian ingatan dalam otak publik berkaitan dengan brand sebuah produk.

Menurut Aaker (1996) ada 3 (tiga) variabel utama dalam asosiasi brand, yaitu brand image (citra brand), brand attitude (sikap brand), dan perceived quality (kualitas yang dirasakan). Brand image adalah kedekatan emosional yang dirasakan oleh publik terhadap suatu brand secara spesifik.

Brand image terdiri dari kepercayaan yang bersifat fungsional dan simbolik. Sedangkan, brand attitude dijelaskan sebagai evaluasi menyeluruh yang dilakukan oleh publik mengenai sebuah brand, baik atau terakhir, perceived quality didefinisikan sebagai penilaian yang diberikan oleh publik terhadap suatu produk atas kualitas menyeluruhnya (Aaker, 1996).

Pada penelitian ini, hal yang menjadi fokus dalam melihat pola pemberitaan adalah asosiasi brand yang disematkan kepada Jokowi sebagai presiden. Dalam penelitian yang sebelumnya dilakukan oleh Salamah (2015), asosiasi brand disebut sebagai tanda awal ekuitas sebuah brand. Asosiasi brand terdiri dari 2 (dua) dimensi, yaitu strength (kekuatan asosiasi) dan tone (positif, negatif, dan netral).

Mengenai Jokowi, sebagai seorang kandidat, penelitian menemukan bahwa brand Jokowi diasosiasikan dengan hal-hal berikut ini:

Tabel 2. Asosiasi Brand Jokowi (Salamah, 2015)

\begin{tabular}{ll}
\hline \multicolumn{1}{c}{ Asosiasi Brand } & Tones \\
\hline Gubernur Jakarta & Positif \\
Merakyat & Positif \\
Blusukan & Positif \\
Tanggungjawab & Positif \\
Muda & Positif \\
\hline
\end{tabular}

Untuk mendapatkan perbandingan yang setara dengan penelitian sebelumnya, maka fokus pada penelitian ini pun akan mencari 2 dimensi asosiasi brand Jokowi, yaitu kekuatan asosiasi dan tone. Halhal ini akan didapatkan dari pemberitaan mengenai Jokowi sebagai presiden di media massa daring. Utamanya, dapat dilihat dari pemilihan kata - kata dalam menggambarkan sosok Jokowi di pemberitaan.

Dalam penelitian ini akan dilihat interaksi antara brand seorang pemimpin politik dengan masyarakat terjadi menggunakan media sebagai perantara. Khususnya dalam demokrasi, peran media menjadi sangat vital dalam fungsi komunikasi politiknya.

Komunikasi politik, terdiri dari tiga unsur, yaitu institusi politik (partai politik maupun politisi), media, dan warga atau audiens (Salamah, 2015). Hakikatnya, warga mendapatkan informasi mengenai institusi politik dari media yang mengambil peran sebagai penyedia informasi, serta melindungi kepentingan warga. Melalui mekanisme ini, media akan mengejar kejelasan mengenai kebijakan - kebijakan. Meski posisinya hanya sebagai perantara, namun posisi media dan institusi politik sama pentingnya. 
Posisi media, sebagai sumber informasi masyarakat serta kendaraan komunikasi pemerintah adalah situasi politik yang termediasi (mediated politics). Masyarakat dalam satuan terkecilnya, individu, mengandalkan media untuk mendapat informasi tentang politik dan isu lainnya. Politik dan elite yang berkuasa pun tidak luput mengandalkan media unruk mengetahui informasi tentang opini publik, kecenderungan masyarakat, hingga cara menjangkau mereka (Salamah, 2015).

Brand seorang pemimpin politik di media massa pun erat kaitannya dengan proses mediasi politik. Brand sebagaimana telah disepakati sebagai simbol, terkait dengan apa yang dipersepsikan oleh audiens (perceived quality), dalam Mitchell dan Olson, 1981. Ada pun dalam proses mediasi politik, realitas terdiri dari tiga kategori (Kaid et al, 1991 dalam McNair, 1995).

1. Realitas objektif, peristiwa politik yang terjadi;

2. Realitas subjektif, realitas peristiwa politik yang dipersepsikan olej aktor politik dan warga; dan

3. Realitas subjektif tingkat kedua, realitas dimana makna terkonstruksi yang diangkat oleh media.

Peran media yang makin dominan sebagai saluran informasi politik, menbuat dewasa ini, realitas politik dalam masyarakat adalah realitas subjektif tingkat kedua. Dominasi logika media juga membuat berita politik justru berbalik arah menjadi berita tabloid. Terlihat dari perubahan trend informasi langsung menjadi sesuatu yang bersifat menghibur (Ross, 2002 dalam Ross dan Nightingale, 2003). Logika media juga mengalahkan logika poltik, yang mengandung dua dimensi, kebijakan dan proses (Patterson, 1993 dalam Stromback, 2008).

Brand pemimpin politik di media massa sebagai akibat dari dominasi peran media dalam komunikasi politik berhubungan erat dengan personalisasi politik. Personalisasi politik, menurut Holtz-Bacha et al (dalam Salamah, 2015), mengacu pada perkembangan terakhir di mana pemimpin politik menjadi jangkar utama interpretasi dan evaluasi dalam proses politik. Kecenderungan ini membuat media menjadi lebih sering menyebut tentang pemimpin politik dibandingkan dengan partainya. Keterpaparan (exposure) di media merupakan kondisi yang memang diperlukan (necessary condition) untuk memastikan daya saing sang pemimpin politik, meski bukan kondisi yang cukup (sufficient condition) untuk kesuksesannya terpilih kembali (Dalton dan Klingemann, 2007).

Penelitian yang sebelumnya dilakukan oleh Salamah (2015), dijabarkan bahwa brand seorang pemimpin politik pada masa kampanye dapat dilihat dengan Brand awareness, Brand association, prototypicality, Brand personality, serta Brand equity. Ditegaskan pula oleh Salamah (2015) bahwa brand pemimpin politik adalah hasil kerja sama antara manajer kampanye dalam mendefinisikan brand, proses mediasi oleh media mempengaruhi brand politik dan citra yang dipersepsikan warga. Tetap ada proses identifikasi serta interpretasi secara mandiri.

Dalam kasus Jokowi, pencalonannya kembali menjadi Presiden RI pada pemilu 2019, maka proses penguatan brand dilakukan melalui praktek kampanye permanen. Kampanye permanen adalah kependekan dari pola manajemen politik yang muncul tanpa adanya rencana, perdebatan, atau diambil secara formal. Heclo (Ornstein dan Mann, 2000) menambahkan bahwa kampanye permanen terdiri dari campuran kompleks tokoh - tokoh politik yang berpengalaman, teknik-teknik komunikasi, serta organisasi pendukung, baik profit dan nonprofit.

Semuanya ditempuh untuk terus mendapatkan restu dari publik (Heclo dalam Ornstein dan Mann, 2000). Proses kampanye politik seringkali tidak disadari oleh publik serta dapat menjadi hasil kolaborasi dari pegawai pemerintahan, warganet acak, hingga oposisi sekali pun. Dengan demikian, polanya harus dibedakan dengan persetujuan publik terhadap berjalannya pemerintahan yang memang esensial dalam sebuah rezim kekuasaan.

Konsep kampanye permanen, sebenarnya juga menggambarkan fokus pemimpin politik terpilih, yang tidak jelas batasannya mengenai waktu dalam menjalankan pemerintahan dan waktu yang sebenarnya digunakan untuk kampanye (Doherty, 2017). Jadi, istilah kampanye permanen digunakan untuk menggambarkannya.

Bagi Blumenthal (1982), kampanye permanen adalah kombinasi dari pembuatan citra dan kalkulasi strategis yang mengubah pemerintahan menjadi kampanye yang terus meneruas dan membuat pemerintahan (pola, gaya) menjadi suatu instrument yang didesain untuk menjaga popularaitas kanididat yang terpilih. Bagi seorang kandidat, setelah terpilih, maka hal yang tidak henti-hentinya dilakukan oleh kandidat adalah memikirkan strategi agar dapat dipilih kembali.

Di Indonesia, lengsernya Soeharto dari puncak kepemimpinan menjadi penanda bergantinya tradisi logika yang hadir di media massa. Dulu, masa Orde Baru, persoalan politik di media massa adalah hal yang tabu untuk diperbincangkan. Media massa adalah subordinat atas kekuasaan, Namun, semenjak reformasi, media massa menjadi bebas untuk menulis hal - hal yang mereka inginkan (Urfan, 2011).

Brants dan Voltmer menggambarkan perubahannya sebagai berikut:

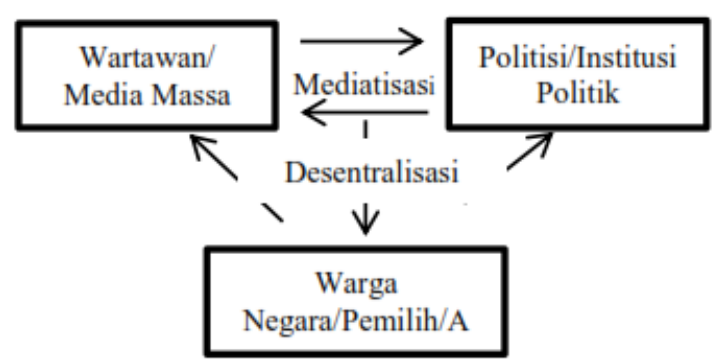

Gambar 4. Perubahan mediatisasi politik (Brants dan Voltmer, $2011: 4$ ) 
Perubahan pola komunikasi politik ini terlihat dari dua sisi dalam hubungan segitiga antara media, politisi, dan pemilihnya. Kedua sisi yang dimaksud adalah hubungan antara politisi dengan media dan hubungan antara elite komunikasi politik (media dan politisi) dengan warga (Salamah, 2015).

Pergeseran hubungan yang diilustrasikan menggunakan garis-garis di atas dari hubungan ketiga pihak tersebut menunjukan bahwa representasi publik terkait politik semakin berpusat pada media. Media kemudian berkembang menjadi sebuah industri yang didorong oleh berbagai tuntutan warga. Dinamika tersebut menjadi penanda btahwa hal yang dapat menarik publik untuk tertarik terhadap politik adalah komunikasi politik menggunakan logika media, budaya pop, dan konsumerisme (Salamah, 2015).

Suatu negara dengan sistem politik yang demokratis tidak dapat memungkiri bahwa apa yang terjadi di dalam pemerintahan adalah hasil dari pilihan politik publik. Maka, kampanye dan berjalannya pemerintahan dianggap memiliki banyak kesamaan karena pemilihan umum dan kampanye kampanyenya tidak dapat dipisahkan. Dalam jangka panjang, apabila janji - janji kampanye tidak dapat dipenuhi, hal ini dapat berpengaruh besar kepada kepercayaan publik dan secara otomatis tidak akan dapat bertahan.

Masa menjabat adalah masa petahana membuktikan hasil kerja mereka guna membangun citra positif sebagai bahan kampanye permanen mereka, baik kepada masyarakat sebagai konstituen, mau pun penyumbang dana.

Dalam manajemen media, proses agenda setting atau penonjolan isu di media massa pun dilakukan (Salamah, 2015), tergantung dari hierarki kepentingan institusi media pada waktu tertentu. Agenda setting muncul karena keterbatasan waktu dan perhatian mlik publik untuk mengikuti dinamika politik sehingga mengandalkan media untuk mengetahui isu - isu utama yang memerlukan perhatian mereka (Cottam, Dietz-Uhler, Mastors, dan Preston, 2004). Bagaimana sebuah berita disampaikan juga memiliki pengaruh terhadap persepsi publik. Apabila suatu berita ditayangkan di halaman depan dengan foto atau ilustrasi, hingga menjadi cerita pembuka di televisi memiliki tingkat kemenyolokan (prominence) yang tinggi, sehingga cenderung mempengaruhi persepsi publik (dalam Salamah, 2015:70).

Agenda setting, terdiri dari 2 (dua) tingkat. Pertama, membentuk isu yang dianggap penting(first level agenda setting) dan tingkat kedua adalah menentukan bagian atau aspek utama yang penting dari isu tersebut (second level agenda setting). Dikutip dari Carroll (2004), first level agenda setting hanya menunjukan kemenonjolan sebuah isu atau topik, sedangkan second level agenda setting juga menunjukan perasaan dan tone selain penjabaran faktar - fakta.

Dalam agenda setting, proses yang dilakukan juga menghasilkan realitas yang telah dikonstruksi oleh media, dengan cara penekanan dan penghilangan (framing) (Eriyanto, 2002). Ketika suatu media melakukan penekanan pada beberapa dimensi isu di satu sisi dan tidak mengikutsertakan aspek lainnya, maka akan memberi efek priming (Domke, Shah, \& Wackman, 1998).

Proses framing ini, menurut Pan dan Kosicki dalam Eriyanto (2002) dilakukan dengan melakukan:

a. Sintaksis: Penyusunan peristiwa dalam bentuk susunan umum berita.

b. Skrip: Mengisahkan fakta atau bagaimana wartawan menceritakan peristiwa ke dalam berita.

c. Tematik: Menulis fakta atau bagaimana wartawan mengungkapkan pandangannya atas peristiwa ke dalam proposisi, kalimat, atau antar hubungan hubungan kalimat yang memberntuk teks secara keseluruhan.

d. Retoris: Menekankan fakta, bagaimana menekankan arti tententu dalam suatu berita.

Dalam proses agenda setting, media salience adalah variabel primer. Terdiri dari 3 (tiga) dimensi, yaitu perhatian (attention); kemenonjolan (prominence); dan valensi (valence) (Kiousis, 2004 dalam Carroll, 2004).

Adapun faktor-faktor yang dianggap memperkuat efek agenda setting adalah kebutuhan akan kognisi, kebutuhan akan orientasi dan keterlibatan politik (Rogers dkk, 1997 dalam Shah, McLeod, Gotlieb \& Lee, 2009). Sementara faktor yang mempengaruhinya adalah relevansi yang dipersepsikan (perceived relevance) dan ketidakpastian (uncertainty) (Salamah, 2015).

Efek agenda setting merupakan dampak agregat dari berbagai pesan dalam jumlah banyak, yang meskipun memiliki konten berbeda namun terkait dengan isu yang sama (Dearing dan Rogers, 1996). Sehingga, kemampuan mempengaruhi isu di media massa sebagai organisasi sangat berkaitan dengan pengaruh sosial (social influence) yang dimiliki oleh kandidat politik.

Peneliti mengumpulkan dari berbagai sumber, bahwa di Indonesia saat ini media massa daring tidak hanya berfokus pada lingkup nasional, namun juga banyak yang berfokus pada pemberitaan lokal dan regional. Dalam setiap berita yang ditampilkan pada laman berita daring, secara umum menyajikan soft news atau feature dan hard news atau berita langsung (aktual) (Suryawati, 2011). Pada setiap konten berita, biasanya akan memuat abstraksi pemberitaan dengan tone yang termanifestasikan dari pemilihan narasumber, serta isu. Melalui jaringan internet, konten berita yang ditampilkan juga dating dari berbagai wilayah, baik lokal, nasional, hingga internasional (Kusumawardani, 2014).

Pada penelitian ini, tiga kanal berita daring yang dipilih adalah Tribunnews.com, Detik.com, dan Liputan6.com, berdasarkan data dari situs Alexa.com per Desember 2017 mengenai 10 besar situs dengan pengunjung teratas. Untuk kategori kanal berita 
daring, tiga besarnya didapatkan oleh laman - laman tersebut.

\section{METODOLOGI PENELITIAN}

Mengenai fokus penelitian yang ingin mengangkat topik mengenai brand Jokowi sebagai presiden setelah 3 (tiga) tahun masa kepemimpinannya melalui berita - berita di media massa daring dalam kurun waktu selama 1 (satu) tahun, yakni semenjak bulan Oktober 2016 - Oktober 2017, peneliti lebih condong untuk menggunakan metode campuran atau mixed methods. Peneliti tidak hanya ingin mendapatkan hasil deskriptif dari citra brand di media daring, namun masuk ke dalam teknis penulisan topik berita untuk seorang petahana. Maka, peneliti memutuskan untuk menggabungkan analisis isi kuantitatif dan kualitatif.

Untuk analisis isi kuantitatifnya, pada penelitian ini, peneliti hanya menganalisis pemberitaan mengenai Presiden Joko Widodo, baik yang diungkapkan oleh narasumber atau pihak ketiga, mau pun pemilihan kata (diksi) untuk menggambarkan Jokowi oleh tiga kanal berita daring versi Alexa.com, situs yang memberikan daftar situs - situs populer.

Peneliti membagi kolom koding dalam analisis isis kuantitatif dengan informasi utama berita (berisi asosiasi brand, isu, sub isu, visibility, valensi, jenis berita, abstraksi pemberitaan, lingkup pemberitaan, dan narasumber).

Sedangkan, untuk analisis isi kualitatifnya, penelitian ini menggunakan metode analisis framing. Metode ini biasa digunakan untuk membedah caracara atau ideologi media dalam mengkonstruksi fakta. Analisis ini juga mencermati strategi seleksi, penonjolan, serta tautan fakta ke dalam berita agar lebih bermakna, menarik, berarti atau lebih diingat, untuk kemudian menggiring interpretasi khalayak sesuai perspektifnya (Sobur, 2006).

Perangkat analisis framing yang akan digunakan adalah konsep milik Zhongdan Pan dan Gerald M. Kosicki karena peneliti menganggap, dalam penelitian, unsur - unsur yang dibutuhkan dalam penelitian ada dalam perangkat Pan dan Kosicki. Peneliti hanya akan melihat analisis framing sesuai dengan kaidah Pan dan Kosicki sebab kebutuhan penelitian untuk memperjelasnya hanya sampai pada tahap yang bersifat teknis.

Objek pada penelitian ini adalah seluruh berita, baik hard news dan soft news mengenai Presiden Jokowi pada bulan Oktober 2016 - 2017 di kanal berita daring Tribunnews.com, Detik.com, dan Liputan6.com.

Pada penelitian ini, kuota pemberitaan untuk analisis isi kuantitatif yang akan dijadikan adalah berjumlah 500 berita daring secara random dengan menggunakan rumus random ' $=$ RAND()' pada program Microsoft Excel. Dari ketiga kanal tersebut pada bulan Oktober 2016 - 2017, didapatkan 758 berita daring dengan rincian, Tribunnews.com berjumlah 144 tautan, Liputan6.com berjumlah 107 tautan, dan Detik.com berjumlah 507 tautan. Lebih lanjut, untuk membuatnya proporsional, ditetapkan batasan bahwa untuk berita dari Tribunnews.com yang harus diteliti berjumlah 95 berita, Liputam6.com berjumlah 70 berita, dan Detik.com berjumlah 335 berita.

Sedangkan untuk analisis penelitian kualitatifnya, peneliti akan memilih berita dari 3 kanal di atas di bulan Oktober 2016 - Oktober 2017 dengan mengambil sampel sentimen pemberitaan 'Positif' dan 'Negatif' dari setiap laman media daring tersebut. Peneliti juga mengusahakan agar setiap berita memiliki peluang yang sama untuk diteliti, maka rumus random sampling kembali akan digunakan.

\section{HASIL DAN DISKUSI}

Menggunakan ketiga laman berita daring yang menjadi objek penelitian, berikut adalah empat kata kunci yang peneliti gunakan untuk menarik data berita di Tribunnews.com, Detik.com, dan Liputan6.com;

1. Kinerja Jokowi;

2. Kinerja pemerintahan Jokowi;

3. Tiga tahun Jokowi; dan

4. Kinerja Presiden.

Peneliti menemukan bahwa proses pengarsipan data yang paling lengkap dengan rentang waktu pencarian hingga satu tahun ke belakang, hanya dapat diakses melalui laman Detik.com dan Tribunnews.com. Dengan keempat kata kunci tersebut, pada laman Liputan6.com, berita terlama yang dapat diakses hanya hingga Agustus 2017.

Peneliti menyimpulkan, bahwa basis data yang dimiliki oleh LIputan6.com memang membatasi proses pencarian dalam arsip mereka. Hal ini, peneliti tengarai untuk mengusahakan pola berbayar, apabila pengakses memiliki kebutuhan pencarian data di dalam laman tersebut.

Untuk temuan mengenai pemberitaan Jokowi dalam 3 tahun pemerintahannya, peneliti mengumpulkan 758 berita dengan rincian Tribunnews.com (144 berita), Liputan6.com (107 berita), dan Detik.com (507 berita). Untuk tahun 2016, hanya ada 72 berita yang terpilih, sisanya 428 berita ditayangkan pada tahun 2017 . Secara umum, di tahun 2016, terdapat 106 berita yang tertayang pada laman pencarian, 652 berita tertarik dari tahun 2017.

Pada bulan Oktober, di tahun 2016 dan 2017, saat pemerintahan memperingati hari jadinya, terdapat sejumlah pemberitaan seperti disajikan dalam Tabel 3. Liputan6.com adalah dianggap paradoks, pada tahun ketiga pemerintahan Jokowi, 2017, rata - rata perhari terdapat $2-4$ berita. Sedangkan, di tahun 2016, rata rata terdapat $1-2$ berita yang tayang mengenai Jokowi dan pemerintahannya.

Tabel 3. Perbandingan berita di laman berita daring Bulan Oktober

\begin{tabular}{lll}
\hline Media & $\mathbf{2 0 1 6}$ & $\mathbf{2 0 1 7}$ \\
\hline Tribunnews.com & 12 & 89 \\
Liputan6.com & 0 & 0 \\
Detik.com & 22 & 65 \\
\hline
\end{tabular}


Mengenai asosiasi brand yang disematkan pada Jokowi, peneliti menemukan bahwa mayoritas kata 'Joko Widodo' atau 'Jokowi' disematkan dengan atribut kata di depannya. Hanya 54 berita dari 500 yang tidak disematkan dengan atribut dan atau tidak menyebutkan nama Joko Widodo dan Jokowi, namun tetap masuk ke dalam jangkauan kata kunci yang peneliti masukan.

Dari 500 berita, 425 berita yang mengasosiasikan Jokowi dengan 'Presiden'. Bahkan, 21 berita menekannya langsung pada judul berita. Peneliti juga membedakan, atribut 'Pak' baik Jokowi atau pun Presiden yang disematkan, untuk 'Pak', ditemukan 59 berita yang menggunakannya dan 'Bapak' dalam 12 berita. Jokowi juga diasosiasikan dengan kepemilikan terhadap pemerintahannya, karena ada 70 berita yang menyematkan pemerintah dan pemerintahan. Lainnya, Jokowi juga terasosiasikan sebagai Mantan Gubernur ( 8 berita), Petahana ( 2 berita), Kepala Negara (3 berita), dan Calon Presiden (1 kali).

Selain asosiasi secara kuantitatif, pada proses kualitatif, peneliti menemukan bahwa ada 72 macam asosiasi brand kualitatif yang disarikan dari berita berita mengenai Jokowi dalam kerangka 3 tahun pemerintahannya. Namun, ada 8 berita yang tidak secara langsung menyebut Jokowi dalam pemberitaannya. Tendensi kata - kata yang menggambarkan Jokowi pun terbagi atas netral, positif, dan negatif. Sepuluh terbanyak asosiasi brand kualitatif brand Jokowi ditemukan seperti dalam Tabel 4.

Untuk isu, peneliti membagi isu menjadi enam topik utama, yaitu Sosial (64 berita), Ekonomi (168 berita), Politik (194 berita), Pemerintahan (33 berita), Keamanan (18 berita), dan Hukum (23 berita). Dari temuan di lapangan, peneliti menemukan bahwa isu Politik dan Ekonomi sebagai isu yang paling mendominasi berita mengenai Jokowi.

Tabel 4. Temuan 10 terbanyak

\begin{tabular}{|c|c|c|c|c|}
\hline No. & $\begin{array}{l}\text { Asosiasi } \\
\text { brand }\end{array}$ & $\begin{array}{l}\text { Total } \\
\text { berita }\end{array}$ & $\begin{array}{l}\text { Tone } \\
\text { kata }\end{array}$ & $\begin{array}{l}\text { Presentase } \\
(\%)\end{array}$ \\
\hline 1. & $\begin{array}{l}\text { Berkinerja } \\
\text { baik }\end{array}$ & 112 & Positif & 22,4 \\
\hline 2. & Tegas & 44 & Positif & 8,8 \\
\hline 3. & $\begin{array}{l}\text { Perlu } \\
\text { peningkatan } \\
\text { kinerja }\end{array}$ & 39 & Netral & 7,8 \\
\hline 4. & $\begin{array}{l}\text { Berkinerja } \\
\text { buruk }\end{array}$ & 30 & Negatif & 6 \\
\hline 5. & $\begin{array}{l}\text { Mengapresias } \\
\text { i kinerja } \\
\text { jajaran }\end{array}$ & 24 & Positif & 4,8 \\
\hline 6. & Bekerja cepat & 23 & Positif & 4,6 \\
\hline 7. & $\begin{array}{l}\text { Dekat dengan } \\
\text { rakyat }\end{array}$ & 20 & Positif & 4 \\
\hline 8. & Optimis & 13 & Positif & 2,6 \\
\hline 9. & Bekerja sama & 13 & Positif & 2,6 \\
\hline 10. & Bekerja cepat & 10 & Positif & 2 \\
\hline
\end{tabular}

Peneliti kemudian mengerucutkannya ke dalam 10 sub-isu terbanyak yang menjadi pemberitaan. Peneliti kemudian menemukan bahwa sub-isu yang menjadi mayoritas pemberitaan mengenai Jokowi adalah 'Kinerja'. Berikut adalah penjabaran daftarnya.

Tabel 5. Temuan 10 sub-isu terbanyak

\begin{tabular}{llll}
\hline No. & Sub-isu & $\begin{array}{c}\text { Total } \\
\text { berita }\end{array}$ & $\begin{array}{l}\text { Presentase } \\
(\boldsymbol{\%})\end{array}$ \\
\hline 1. & Kinerja & 115 & 23 \\
2. & Infrastruktur & 44 & 8,8 \\
3. & Apresiasi & 24 & 4,8 \\
4. & Survey & 22 & 4,4 \\
5. & Reshuffle & 21 & 4,2 \\
6. & Dukungan & 20 & 4 \\
7. & Kunjungan & 18 & 3,6 \\
8. & Kritik & 16 & 3,2 \\
9. & Energi & 15 & 3 \\
10. & Individu & 15 & 3 \\
\hline
\end{tabular}

Pemberitaan daring sistem paragrafnya tidak sama dengan berita di media cetak. Sistem paragraf di media daring, seringkali ditemukan hanya terdiri dari satu kalimat yang kemudian diberikan spasi untuk menandakan bahwa kalimat tersebut adalah satu paragraf. Berdasarkan temuan di lapangan, peneliti tidak jarang menemukan penempatan deskripsi asosiasi brand Jokowi justru berada di paragraf lebih dari 10. Tabel 6 berisi penempatan deskripsi asosiasi brand Jokowi yang peneliti temukan dari 500 berita. Namun, pada akhirnya, mayoritas berita yang diteliti tetap menempatkan deskripsi asosiasi brand Jokowi di paragraf pertamanya (282 berita).

Tabel 6. Visibility (penempatan paragraf)

\begin{tabular}{ccc}
\hline Paragraf & Total berita & Presentase (\%) \\
\hline 1 & 282 & 56,4 \\
2 & 59 & 11,8 \\
3 & 51 & 10,2 \\
4 & 34 & 6,8 \\
5 & 25 & 0,5 \\
6 & 13 & 0,26 \\
7 & 11 & 0,22 \\
8 & 7 & 0,14 \\
10 & 6 & 0,12 \\
13 & 2 & 0,04 \\
14 & 2 & 0,04 \\
9 & 1 & 0,02 \\
11 & 1 & 0,02 \\
12 & 1 & 0,02 \\
16 & 1 & 0,02 \\
\hline
\end{tabular}

Sentimen pemberitaan mengenai Jokowi dalam kerangka 3 tahun pemerintahannya didominasi oleh berita 'Netral' (239 berita). Pasalnya, keberimbangan berita terbaca jelas dari poin pemberitaan, serta kebanyakan beritanya hanya berkaitan dengan seremonial yang dihadiri oleh Jokowi. Peneliti juga menemukan bahwa sentiment 'Positf' (191 berita) masih lebih banyak daripada pemberitaan 'Negatif' (239 berita). Gambar 5 memperlihatkan sebaran beritanya. 


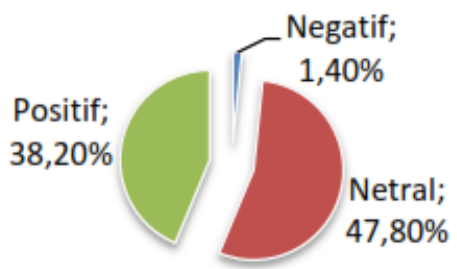

Gambar 5. Valensi

Peneliti juga menemukan bahwa pemberitaan di Liputan6.com dan Detik.com lebih cenderung bersentimen 'Netral'. Sedangkan pemberitaan mengenai Jokowi dalam kerangka 3 tahun pemerintahan di Tribunnews.com cenderung bersentimen 'Positif'. Berikut adalah tabel temuannya:

Tabel 7. Perbandingan tiap laman berita daring (dalam persen)

\begin{tabular}{clcc}
\hline No. & $\begin{array}{l}\text { Abstraksi } \\
\text { pemberitaan }\end{array}$ & $\begin{array}{c}\text { Total } \\
\text { berita }\end{array}$ & $\begin{array}{c}\text { Presentase } \\
(\%)\end{array}$ \\
\hline 1. & Kinerja jajaran & 42 & 8,4 \\
2. & $\begin{array}{l}\text { Hasil survey } \\
\text { 3. }\end{array}$ & 31 & 6,2 \\
3. & $\begin{array}{l}\text { Pembangunan } \\
\text { infrastruktur }\end{array}$ & 25 & 5 \\
& $\begin{array}{l}\text { Kinerja 3 tahun } \\
\text { 4. }\end{array}$ & 17 & 3,4 \\
& pemerintahan & & 3,2 \\
& Dukungan & & \\
berbagai & kalangan untuk & 16 & \\
5. & pemerintahan & & 3,2 \\
& Elektabilitas & 16 & 4 \\
presiden & Dukungan & 20 & 3,6 \\
7. & Kunjungan & 18 & 3,2 \\
8. & Kritik & 16 & 3 \\
9. & Energi & 15 & 3 \\
10. & Individu & 15 & \\
\hline
\end{tabular}

Dalam berita yang peneliti kumpulkan, ditemukan bahwa pemberitaan mengenai Jokowi dalam kerangka 3 tahun pemerintahannya didominasi oleh berita - berita 'Hard News (434 berita)' dibandingkan dengan jenis berita 'Soft News (66 berita)'. Perbandingannya diberikan dalam Tabel 8 .

Tabel 8. Perbandingan jenis berita (dalam persen)

\begin{tabular}{cc}
\hline Hard News & Soft News \\
\hline 86,8 & 13,2 \\
\hline
\end{tabular}

Hal ini sejalan dengan temuan pada bagian valensi yang mayoritas memang berita - berita netral dikarenakan bersifat langsung serta bertemakan kegiatan seremonial yang dihadiri oleh Jokowi sebagai seorang presiden.

Pemberitaan dalam kerangka 3 tahun pemerintahan Jokowi sangat beragam dalam temuan peneliti di tiga laman media daring tersebut. Mayoritas pemberitaan yang dikumpulkan pun memiliki inti pemberitaan tidak sama. Peneliti kemudian menemukan lima tren abstraksi pemberitaan yang sering muncul di 500 berita objek penelitian ini yaitu:

Tabel 9. Perbandingan abstraksi pemberitaan

\begin{tabular}{|c|c|c|c|}
\hline Sentimen & $\begin{array}{l}\text { Tribun } \\
\text { news.co } \\
\text { m }\end{array}$ & $\begin{array}{l}\text { Detik.c } \\
\text { om }\end{array}$ & $\begin{array}{l}\text { Liputan } \\
\text { 6.com }\end{array}$ \\
\hline Netral & 28 & 167 & 44 \\
\hline Positif & 45 & 120 & 26 \\
\hline Negatif & 22 & 48 & - \\
\hline
\end{tabular}

Peneliti juga menemukan bahwa pemberitaan mengenai Jokowi didominasi oleh berita-berita dengan lingkup 'Nasional (428 berita)', dibandingkan cakupan 'Lokal (53 berita)' dan 'Internasional (19 berita)'. Gambar 6 memberikan perbandingannya.

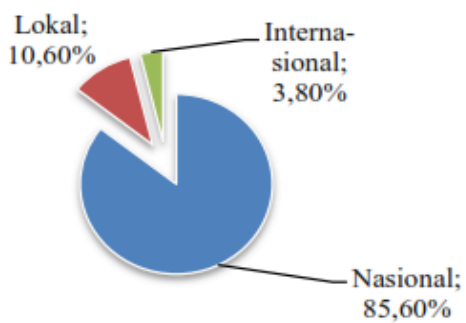

Gambar 6. Lingkup pemberitaan

Peneliti menemukan bahwa dari 500 berita yang menjadi objek penelitian, 'Pejabat Eksekutif' merupakan narasumber utama di 242 berita. Perbandingan antara 'Pejabat Eksekutif', 'Pejabat Legislatif (16 berita)', 'Pejabat Yudikatif (1 berita)', 'Politikus (53)', 'Birokrat (48)', dan 'Umum (156 berita)', dijabarkan dalam tabel berikut ini:

Tabel 10. Perbandingan narasumber (dalam persen)

\begin{tabular}{llllll}
\hline $\begin{array}{l}\text { Pjbt } \\
\text { Ekse- } \\
\text { kutif }\end{array}$ & $\begin{array}{l}\text { Pjbt } \\
\text { Legis- } \\
\text { latif }\end{array}$ & $\begin{array}{l}\text { Pjbt } \\
\text { Yudi- } \\
\text { katif }\end{array}$ & $\begin{array}{l}\text { Poli- } \\
\text { tikus }\end{array}$ & $\begin{array}{l}\text { Biro- } \\
\text { krat }\end{array}$ & Umum \\
\hline 48,4 & 3,2 & 0,02 & 10,6 & 9,6 & 31,2 \\
\hline
\end{tabular}

Dari 242 berita yang menggunakan 'Pejabat Eksekutif' sebagai narasumbernya, peneliti menemukan bahwa 'Jokowi' menjadi narasumber utama di 138 berita $(27,6 \%)$. Peneliti juga melakukan penelitian analisis isi kualitatif atau metode analisis framing untuk memperdalam hasil yang didapatkan. Seperti yang sudah dijelaskan di Bab 3, peneliti mengambil mengambil sampel sentimen pemberitaan 'Positif' dan 'Negatif' dari setiap laman Tribunnews.com, Detik.com, dan Liputan6.com.

Berdasarkan penelitian kuantitatif yang juga peneliti lakukan, ditemukan bahwa pada Liputan6.com tidak ada berita dengan sentimen pemberitaan 'Negatif'. Maka, untuk laman Liputan6.com, peneliti hanya menelaahnya 
berdasarkan berita bersentimen 'Positif' saja. Ada lima berita yang menjadi objek penelitian untuk analisis framingnya.

Agar setiap berita dengan sentimen 'Positif' dan 'Negatif' memiliki peluang yang sama, peneliti juga menggunakan pola random sampling seperti pada penelitian analisis isi secara kuantitatifnya. Berikut adalah list berita dari setiap laman yang menjadi objek dalam penelitian ini:

Tabel 11. Daftar berita

\begin{tabular}{|c|c|c|}
\hline $\begin{array}{l}\text { Laman } \\
\text { Berita Daring }\end{array}$ & Judul Berita & Sentimen \\
\hline & $\begin{array}{l}\text { Jokowi Sangat Komitmen } \\
\text { Menggenjot Infrastruktur }\end{array}$ & Positif \\
\hline $\begin{array}{l}\text { Tribunnews.c } \\
\text { om }\end{array}$ & $\begin{array}{l}\text { Tiga Tahun Jokowi-JK } \\
\text { Lapangan Kerja Informal } \\
\text { Banyak Terbuka, Ini } \\
\text { Komentar Faisal Basri } \\
\text { Sektor Pariwisata Jadi }\end{array}$ & Negatif \\
\hline Detik.com & $\begin{array}{l}\text { Primadona Perekonomian } \\
\text { Baru } \\
\text { Jokowi: Kepercayaan }\end{array}$ & Positif \\
\hline Liputan6.com & $\begin{array}{l}\text { Publik Pacu Pemerintah } \\
\text { Bekerja Lebih Keras }\end{array}$ & Positif \\
\hline
\end{tabular}

Peneliti menemukan bahwa pada berita di Tribunnews.com dengan sentimen positif, sudah terlihat dari pemilihan judul yang hiperbola serta kalimat penutup dari narasumber, keduanya menekankan pada komitmen tinggi presiden dalam pembangunan infrastruktur dan harapan dukungan masyarakat Indonesia.

Untuk berita bersentimen negatifnya, justru harus dibaca secara utuh. Pasalnya, meski judul yang diberikan cenderung mengarahkan pembaca awam kepada apresiasi atas kinerja pemerintahan Jokowi, namun sebenarnya jurnalis bermaksud sebaliknya. Kata 'lapangan informal' pada judul, justru sebenarnya merujuk pada ketersediaan lapangan kerja dengan gaji tidak tetap, seperti yang dijelaskan lebih lanjut dalam isi berita. Ada pun penekanan data yang diberikan sebenarnya mengindikasikan bahwa berita ini tidak sepenuhnya ingin dibuat menjadi negatif. Sebab, data kenaikan dari $56 \%$ menjadi $58 \%$ tidak memiliki selisih yang dramatis.

Pada kasus Detik.com, berita bersentimen positif adalah berita yang datang dari internal Kementerian Pariwisata untuk mengekspose hasil pekerjaan mereka. Sehingga, fokusnya memang kesuksesan kementerian di era kepemimpinan Jokowi. Pemilihan judul berita yang menggunakan kata 'primadona' telah mengindikasikan dari awal bahwa berita ini memiliki sentimen positif bagi pemerintahan Jokowi di bidang pariwisata. Jurnalis untuk berita ini terlalu fokus pada data, capaian, dan keberhasilan Kementerian Pariwisata sehingga tidak terlalu memperhatikan pemilihan kalimatnya.

Berita bersentimen negatif di Detik.com bersumber dari partai oposisi. Namun, peneliti menemukan bahwa jurnalis berusaha menyeimbangkan berita dengan menuliskan, 'Namun Riza menilai pembangunan infrastruktur cukup positif' pada bagian lead berita.

Terakhir, di Liputan6.com, peneliti menemukan bahwa berita ini bersifat positif dengan pemilihan judul yang menempatkan kutipan pernyataan presiden, 'Jokowi: Kepercayaan Publik Pacu Pemerintah Bekerja Lebih Keras'. Pemilihan kata 'Bekerja Lebih Keras' menurut peneliti diasosiasikan bahwa Jokowi dan pemerintahan tidak berpuas diri dan terus bekerja demi kepentingan publik.

\section{KESIMPULAN}

Ada pun kesimpulan dari penelitian ini adalah:

1. Pada 3 tahun pemerintahanyya brand Jokowi dalam media massa adalah positif.

2. Brand seorang Jokowi pada masa kampanye dan saat menjabat tidak memiliki perbedaan yang jauh. Keduanya masih sama-sama memiliki memiliki konotasi positif.

3. Jokowi disimpulkan sebagai seorang tokoh media darling, dimana ketiga media berita yang tayang kebanyakan membelanya, baik secara implisit maupun eksplisit.

4. Isu yang memperkuat brand Jokowi dalam gaung 3 tahun pemerintahannya adalah isu-isu di Politik, khususnya berkaitan dengan dukungan dari partai koalisi dan hasil survei yang hampir seluruhnya dalam pemberitaan memberikan angin segar, dikarenakan berisi kepuasaan serta kepercayaan publik kepada Jokowi. Ini termasuk isu di bidang Ekonomi, khususnya kinerja pembangunan masif dan capaian infrastruktur.

5. Sementara isu yang dianggap memperlemah Brand Jokowi dalam laman berita daring adalah kritik-kritik yang diberikan oleh oposisi berkenaan dengan kinerja. Mengasosiasikan Jokowi dengan kinerja yang buruk karena hasil pekerjaannya diklaim tidak membawa perubahan. Ada pun tema-tema pemberitaan yang tayang mengenai Jokowi justru tidak menyebutkan personanya secara langsung. Melainkan deskripsi melalui berita yang berhubungan dengan kinerja jajarannya, hasil survei, serta capaian pekerjaan, hingga dukungan yang diberikan kepada pemerintahannya. Menurut peneliti, hal ini termasuk ke dalam proses kampanye permanen yang dilakukan oleh Jokowi sebagai seorang petahana.

\section{DAFTAR PUSTAKA}

Aaker, D. (1996). Building Strong Brands. New York: The Free Press.

Bawn, K., Cohen, M., Karol, D., Masket, S., Noel, H. \& Zaller, J. (2012). A theory of political parties: group, policy, demands and nominations in American politics. Perspective on Politics, 10(3), 571-597.

Blumenthal, S. (1982). The permanent campaign. New York: Simon and Schuster.

Brockhoff, Thomas, K. \& Dirk, K. (1994). Die BiirgerWehr. Die Zeit. 21 January 1994 
Dalton, R. J. \& Klimengann, H.-D. (ed.). (2007). The Oxford handbook of political behavior. Oxford: Oxford University Press.

Dearing, J. W. \& Everett, R. (1996). Agenda setting. thousand oaks: Sage Publishing Inc.

Doherty, B. (2017), The Rise of the President's Permanent Campaign. University of Kansas [20 Desember 2017].

Domke, D., Dhavan, V. S., \& Daniel, B. W. (1998). Media priming effects: accessibility, association, and activation. International Journal of Public Opinion Research, 10(1), 51 - 74 .

Eriyanto (2002). Analisis framing: konstruksi, ideologi, dan politik Media. Yogyakarta: PT. LKis Pelangi Aksara.

Esser, F. \& Barbara, P. (2004). Comparing political communication: theories, cases, and challenges. Cambridge: Cambridge University Press.

Fachrudin, F. (2017). Survei CSIS: 68,3 persen responden puas kinerja pemerintahan Jokowi. Kompas.com. 2017 [20 Desember 2017].

Firmanzah (2007). Marketing politik antara pemahaman dan realitas. Jakarta: Yayasan Obor Indonesia

Guzman, F. \& Vicenta, S. (2009). A political brand image scale: are political candidates brand? Brand Management, 17(3), 207 - 227.

Heclo, H. (2000). Campaigning and governing: a conspectus, dalam Ornstein, Norman J. \& Thomas E. . Mann (ed.). The permanent campaign and its future. Washington: American Enterprise Institute and The Brookings Institution. pp. $1-37$.

Heding, T., Charlotte, F. K. \& Mogens, B. (2010). Brand management: research, theory and practice. London: Routledge.

Hootsuite (2017). New research reveals global social media use increased by 21 percent in 2016 by Media Team [20 Desember 2017].

Indrananto, C. (2012). Local leaders and agents: dramaturgy on political communications of city mayor Joko Widodo of Solo. Tesis dari Universitas Indonesia.

Kapferer, J. N. (2008), The New Strategic Brand Management: Creating and Sustaining Brand Equity Long Term. London: Kogan Page.

Keller, K. L. (2003). strategic brand management: building, measuring, and managing brand equity. 2nd Ed. Prentice Hall.

Kornberger, M. (2010). Brand society: how brand transform management and life style. Cambridge, UK: Cambridge University Press.

Lees-Marshment, J. (2009). Political marketing: principles and applications. Abingdon, Oxon, New York: Routledge.

Mayhew, D. R. (1974). Congress: the electoral connection. Connecticut: Yale University Press.

Nimmo, D. (1978), Political Communication and Public Opinion in America. Santa Monica, California: Goodyear Publishing Company.

Perbawaningsih, Y. (2013). media darling: apa yang salah? Bernas Jogja [20 Desember 2017].

O'Cass, A. (1996), Political marketing and the marketing concept. European Journal of Marketing, 30 (10/11), $45-61$.

Ross, K. \& Virginia, N. (2003), Media and Audiences: New Perspectives. London: Open University Press.

O'Shaugnessy, N. (2001). The marketing of political marketing. Journal of Marketing, 35(9/10), 1407 1410.

Salamah, U. (2015), Brand pemimpin politik. Jakarta: Makna Informasi.
Sinaga, E. K. (2014). KPU: Jokowi-JK peroleh suara 53,15 persen dan Prabowo-Hatta 46,85 Persen.Tribunnews.com [20 Desember 2017].

Shah, D. V., Douglas, M. M., Melissa, R. G. \& Nam, J. L. (2009). Framing and agenda setting dalam nabi, Robin L. \& Mary Beth Oliver (ed.). The Sage Handbook of Media Processes and Effects. Thousand Oaks, CA: Sage Publications.

Sobur, A. (2006). Analisis teks media. Bandung; PT Remaja Rosdakarya

Stromback, J. (2008). Four phases of mediatization: an analysis of the mediatization of politics. Press/Politics, 13(3). London: Sage Publications.

Suryawati, I. (2011), Jurnalistik Suatu Pengantar. Bogor: Ghalia Indonesia.

Taylor, D. G. (2010). I speak, therefore i am: identity and self- construction as motivation to engage in electronic word of mouth. Disertation from University of North Texas.

Urfan, N. F. (2011). Membaca gejala "mediatisasi" politik di Indonesia. Jurnal Komunikasi, 6 (1), Oktober 2011.

Zavattaro, S. M. (2010). Brand Obama: the implications of a branded president. Administrative Theory and Praxis, 32(1), 123 - 128. 